\title{
Application of a micro-respirometric volumetric method to respiratory measurements of larvae of the Pacific oyster Crassostrea gigas
}

\author{
Philippe Goulletquer ${ }^{1, a}$, Maciej Wolowicz ${ }^{2}$, Adam Latala ${ }^{2}$, Craig Brown ${ }^{4}$ and Simon Cragg ${ }^{4}$ \\ ${ }^{1}$ Genetic-Aquaculture \& Pathology Research Laboratory, Ifremer, BP 133, 17390 Ronce les Bains, France \\ 2 Department of Marine Ecosystems Functioning, Institute of Oceanography, University of Gdansk, Al. Marszalka J. Pilsudskiego 46, \\ 81-378 Gdynia, Poland \\ 3 Scottish Association for Marine Science, Dunstaffnage Marine Laboratory, Dunbeg, Oban, Argyll, PA37 1QA, Scotland, UK \\ ${ }^{4}$ Institute of Marine Sciences, School of Biological Sciences, University of Portsmouth, Ferry Road, Portsmouth, PO4 9LY, UK
}

Received 29 January 2004; Accepted 7 May 2004

\begin{abstract}
The application of a simple, fast and reliable volumetric microrespirometric method to assess respiration of bivalve larvae is discussed. As a model, $C$. gigas larvae of various sizes were used. Metabolic activity of veliger larvae was assessed by measuring respiratory rate for use in ecophysiological modelling. As an example of the application of this approach, additional measurements of veliger respiratory rates were carried out to assess the effect on larval metabolism of different concentrations of leachate from wood treated with chromated copper-arsenate (CCA). Veligers of Crassostrea gigas (length from 95 to $331 \mu \mathrm{m}$ ) were fed with a mixture of Isochrysis galbana and Chaetoceros pumilum cells. Experiments were performed in a $20{ }^{\circ} \mathrm{C}$ constant seawater temperature. The wet and dry weight of four length $(L$, in $\mu \mathrm{m})$ classes of larvae were obtained from which the relationship between total dry weight and veliger length was derived $\left\{D W=e^{(3.27+L \times 0.0154)}\right\}\left(R^{2}=99 \%\right)$. Moreover, tissue dry weight $(T D W$; in $n g)$ was calculated according to Gerdes (1983). Since the mathematical model between larval length and respiratory rate explained $88 \%$ of the total variability, a more conservative approach using oyster larval dry meat weight (in $n g$ ) and respiratory rate (in $\mu \mathrm{lO}_{2} \mathrm{~h}^{-1}$ ) was developed to establish a linear model explaining $94.5 \%$ of the variability: Resp. $=-3.849 \times 10^{-4}+5.211 \times 10^{-6} \times$ $T D W$. These experiments provided updated figures of $C$. gigas larval respiratory rates for use in ecophysiological models. The relationship between tissue dry weight and respiratory rate was close to previous estimates obtained by Gerdes (1983) and Hoegh-Guldberg and Manahan (1995) at $25^{\circ} \mathrm{C}$ and $20^{\circ} \mathrm{C}$ respectively. Our experiments demonstrate that volumetric microrespirometry is suitable for assessing larval respiratory rate and therefore can be used to assess impacts of pollutants on an early larval stage. Oysters exposed to leachates from chromated copper arsenate (CCA) treated timber at $5 \mathrm{~kg} \mathrm{~m}^{-3}$ showed initially highly variable respiratory rates while those rates decreased drastically for a $15 \mathrm{~kg} \mathrm{~m}^{-3}$ CCA treatment exposure. Among bioindicators using physiological response to assess pollutant effects, swimming activity and respiratory rates can be compared, the later showing a significant response at a lower pollutant concentration.
\end{abstract}

Key words: Respiratory rate / Metabolism / Larvae / Volumetric micro-respirometry / CCA / Leachate / Crassostrea gigas

Résumé - Application d'une méthode volumétrique de micro-respiration pour l'évaluation de la respiration larvaire chez l'huître creuse Crassostrea gigas. L'utilisation d'une méthode simple, rapide et fiable de microrespiration volumétrique est discutée. Les larves de l'huître creuse $C$. gigas de différentes tailles sont utilisées en tant que modèle biologique. L'activité métabolique de larves véligères est estimée par une mesure de respiration afin d'être utilisée dans le cadre d'une modélisation en écophysiologie. A titre d'exemple, cette méthode est appliquée pour tester l'effet de différentes concentrations de lixiviats issus de bois traité sous pression au chrome-cuivre-arsenic (CCA) sur le métabolisme larvaire. Les véligères de Crassostrea gigas (taille de 95 à $331 \mu \mathrm{m}$ ) sont nourries d'un mélange de cellules phytoplanctoniques d'Isochrysis galbana et de Chaetoceros pumilum. Les expérimentations sont conduites à une température d'eau de mer constante à $20^{\circ} \mathrm{C}$. Les poids frais et secs de 4 classes de taille $(L$, en $\mu \mathrm{m})$ de larves sont mesurés afin d'établir un modèle $\left\{D W=e^{(3.27+L \times 0.0154)}\right\}\left(R^{2}=99 \%\right)$. Le poids de chair sec $(T D W$, en $n g)$ est calculé

a Corresponding author: Philippe.Goulletquer@ifremer.fr 
selon Gerdes (1983). Le modèle mathématique entre la taille et le taux de respiration n'expliquant que $88 \%$ de la variance totale, un modèle linéaire a été établi entre le taux de respiration $\left(\mathrm{en} \mu \mathrm{lO}_{2} \mathrm{~h}^{-1}\right.$ ) et le poids de chair sec de la larve (en $n g$ ), expliquant $94.5 \%$ de cette variance : Resp. $=-3.849 \times 10^{-4}+5.211 \times 10^{-6} \times T D W$. Ces expérimentations ont permis d'actualiser les taux de respiration larvaire de $C$. gigas pour le développement de modèles écophysiologiques. Le modèle obtenu est relativement proche des estimations obtenues par Gerdes (1983) et Hoegh-Guldberg and Manahan (1995), respectivement à des températures de $25^{\circ} \mathrm{C}$ et $20^{\circ} \mathrm{C}$. Nos expérimentations montrent que la méthode de micro-respiration volumétrique est appropriée pour l'estimation du métabolisme respiratoire larvaire comme pour celle de l'impact de polluants aux premiers stades de développement. Des huîtres exposées à des lixiviats de bois traités sous pression au chrome-cuivre-arsenic (CCA) à $5 \mathrm{~kg} \mathrm{~m}^{-3}$ ont montré une augmentation de la variabilité de la réponse respiratoire, avec une forte réduction de celle-ci à des lixiviats issus d'un traitement CCA à $15 \mathrm{~kg} \mathrm{~m}^{-3}$. Parmi les bioindicateurs utilisant une réponse physiologique pour évaluer les effets de polluants, la mesure du métabolisme respiratoire montre une réponse significative à des teneurs plus faibles en contaminants comparée à une mesure d'activité natatoire.

\section{Introduction}

For benthic species with planktonic development, larval survival is the key factor for recruitment and population dynamics. For example, regular yearly recruitment of $C$. gigas is the key to sustaining oyster culture in several countries (Héral 1989). As irregular recruitment has been observed recently in several French rearing areas, an improved understanding of larval physiology is of considerable interest. Whereas most research on bivalve larvae is aimed at assessing growth, development, metamorphosis and settlement, only limited studies have focused on the quantification of physiological functions (Bayne 1983; Bayne and Newell 1983). Larval survival rate is determined by the interaction of numerous factors, including initial energy reserves (e.g., lipid content, Gallager and Mann 1986) and the combined effects of environmental conditions (Goulletquer et al. 1994; His et al. 1989). Moreover, the capacity to store sufficient internal energy by feeding to sustain metabolism, then metamorphosis and set, is a critical factor affecting survival rate (Roland and Broadley 1989; His et al. 1989; Powell et al. 2002).

Ecophysiological models are a useful tool for establishing relationships between physiological functions and environmental conditions; for assessing, for example, effects of environmental factors on growth and on scope for growth (SFG). These measures can then be used to develop ecosystem models (Héral 1993; Smaal and Widdows 1994). Whereas several ecophysiological models have been developed for adult oysters and mussels (e.g., Ren and Ross 2001), only a few concern larvae (Sprung 1984; Dekshenieks et al. 1993; Bochenek et al. 2001; Powell et al. 2002). In particular, little information exists on larval oxygen consumption, one of the functions required for parameterizing energy flow (Gerdes 1983; Hoegh-Guldberg and Manahan 1995). The fact that measurements of oxygen consumption by larvae are time consuming and difficult from the technical point of view has resulted in the evaluation of respiratory cost being primarily based upon only a few published studies (Bochenek et al. 2001). The few existing data were obtained using very different methods: Cartesian divers (Zeuthen 1947), micro-respirometry (Grunbaum et al. 1955; Marsh and Manahan 1999; Peck and Prothero-Tomas 2002), calculation of oxygen equivalents of biochemical losses (Gabbott and Holland 1973), polarographic oxygen sensors (Gnaiger and Forstner 1983; Olson et al. 1987; Macdonald 1988), closed chambers of various capacities equipped with a stirrer and a Clark electrode (Gerdes 1983), microcathode oxygen electrode (Lu et al. 1999) or coulometric respirometry
(Hoegh-Guldberg and Manahan 1995). Furthermore, the concentrations of larvae required to measure a decline in oxygen tensions are usually high (up to 290 individuals per ml) (Jaeckle and Manahan 1989; Hoegh-Guldberg and Manahan 1995). Only recently, Peck and Whitehouse (1999) used the extreme sensitivity of the colouximeter to assess individually respiratory rate of invertebrate larvae.

This paper aims to 1) assess the suitability of the volumetric micro-respirometer as a rapid and reliable method for measurement of larval respiration, and 2) provide a new evaluation of respiratory rates for various sizes of $C$. gigas larvae.

Respiratory rates are also useful for ecotoxicology. In this study, the potential of this method of measuring effects of contaminants on respiration is demonstrated using larvae exposed to leachate from wood treated with a preservative used to protect wood from marine borers. The use of this preservative (chromated copper arsenate - CCA - oxides chemically bonded to the wood) in the marine environment, has recently come under scrutiny with regard to environmental impact (Brown et al. 2003).

\section{Materials and methods}

\subsection{Experimental conditions}

Experiments were conducted with veligers of Crassostrea gigas (Thunberg), reared in laboratory conditions derived from traditional hatchery methods (Helm and Millican 1977). Larvae were kept in round $300 \mathrm{dm}^{3}$ aerated vessels in seawater at a temperature of $20 \pm 0.5^{\circ} \mathrm{C}$ and salinity of $34.6 \pm 0.5 \mathrm{psu}$. Seawater was changed every day and a mixture of Isochrysis galbana and Chaetoceros pumilum cells $\left(30 \times 10^{-4}\right.$ cell cm $\left.{ }^{-3}\right)$ was added as a food. Algal culture was performed in Conway medium without $\mathrm{Fe}$, and maintained at $16-17^{\circ} \mathrm{C}$ and 32 psu at constant illumination. For experiments, cultures of the unicellular algae in logarithmic phase of growth were used. Larvae used for respiration experiments ranged in maximum dimension $(L)$ from $95 \pm 1 \mu \mathrm{m}$ (D-shaped veligers) to $331 \pm 13 \mu \mathrm{m}$. The respiratory measurements were performed at intervals over 22 days up to the beginning of metamorphosis.

To determine growth rate, the size measurements of veligers were taken daily on 120 to 240 individuals, using a Nikon V-12A microscope equipped with a micrometer (Nikon SC-112) and with shape-size projector. Larval activity was also noted. 
Table 1. Multiplicative model of respiratory rate as a function of larval size; ANOVA results.

\begin{tabular}{cccccc}
\hline Source & $\begin{array}{c}\text { Sum of } \\
\text { Squares } \\
\left(\times 10^{-4}\right)\end{array}$ & $d f$ & $\begin{array}{c}\text { Mean } \\
\text { Square } \\
\left(\times 10^{-4}\right)\end{array}$ & $F$ & Prob. \\
\hline Model & 57.7148 & 1 & 57.7148 & 286.3 & $<0.001$ \\
\hline Residual & 7.0563 & 35 & 0.2016 & & \\
\hline Total (Corr.) & 64.7711 & 36 & & & \\
\hline
\end{tabular}

Corel. Coef. $=0.94 ; R^{2}=88 \%$.

Weight measurements were taken for four different length size classes of larvae $(100,150,200$ and $250 \mu \mathrm{m})$ using a Sartorius RC 210 D balance. Larvae were sieved on various mesh size from culture trays commonly used in oyster nursery, counted, weighed $(W W)$, then dried at $55-60{ }^{\circ} \mathrm{C}$ to the constant weight and reweighed $(D W)$. Tissue dry weight $(T D W)$ was calculated using existing data showing that larval shell weight makes up to $75 \%$ of total dry weight (Walne 1965; Millar and Scott 1967).

\subsection{Respiratory measurements}

Respiratory rates were determined with a volumetric micro-respirometer composed of five micro-chambers connected individually to capillaries. Four chambers contained oyster larvae in seawater, the fifth chamber was used as a control for air pressure changes. A suspended drop of $\mathrm{KOH}$ was added to each chamber, so that changes in gas volume were caused only by oxygen consumption by larvae (for detailed description of microrespirometer see Zurzycki and Starzecki 1971; Goulletquer et al. 1999). All measurements were made at $20 \pm 0.1{ }^{\circ} \mathrm{C}$ using an ultrathermostat to maintain constant temperature. This temperature is representative of natural environmental conditions when natural spawnings of Crassostrea occur. Between 57 to 560 larvae per chamber were used. The number of larvae in each chamber was determined under the microscope after the respiratory measurements were completed. The respiratory rate was measured every $10 \mathrm{~min}$ for 60 to $120 \mathrm{~min}$ and expressed as a $\mu \mathrm{lO}_{2} \mathrm{~h}^{-1}$ larva $^{-1}$. Leachates from Scots pine (Pinus sylvestris) sapwood, untreated (control) or treated to target retentions of CCA oxide formulation (Celcure AO, Rentokil, UK) of 5 and $15 \mathrm{~kg} \mathrm{~m}^{-3}$ were used to test the sensitivity of respiratory measurements. CCA treatment involves the impregnation of preservative solution into the timber by means of a cycle of periods of pressure and vacuum, then followed by a fixation period. Chemical reactions lead to binding the CCA components within the wood cell walls. CCA uptake is expressed as $\mathrm{kg}$ preservative per cubic meter of wood $\left(\mathrm{kg} \mathrm{m}^{-3}\right)$. Leachates were prepared according to Praël et al. (2001) protocols, i.e. treated blocks were immersed in agitated seawater of approximately 34 psu for 24 hours at $24 \pm 0.1^{\circ} \mathrm{C}$.

\subsection{Data analysis}

All statistical analysis were performed using the software Statgraphics(C) Plus.

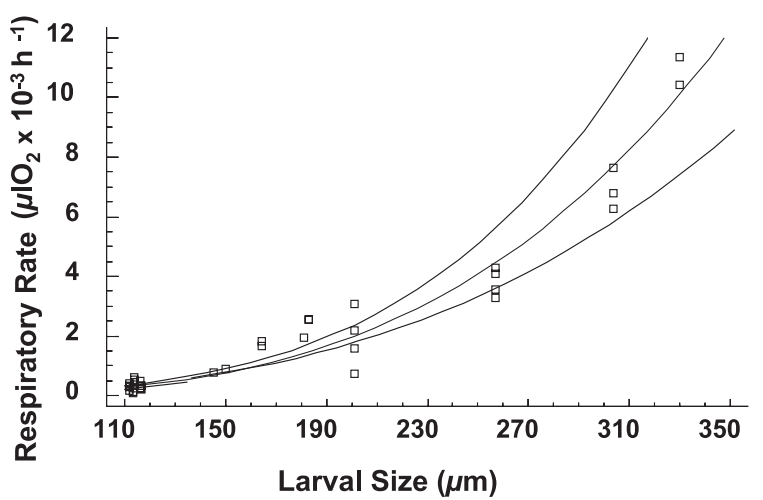

Fig. 1. Relationship between oyster larval size and respiratory rate per larva, using a multiplicative model $\left(R^{2}=88 \%, n=37\right)(95 \%$ confidence limits).

Table 2. Linear model of respiratory rate as a function of dry meat weight; ANOVA results.

\begin{tabular}{cccccc}
\hline Source & $\begin{array}{c}\text { Sum of Squares } \\
\left(\times 10^{-4}\right)\end{array}$ & $d f$ & $\begin{array}{c}\text { Mean Square } \\
\left(\times 10^{-4}\right)\end{array}$ & $F$ & Prob. \\
\hline Model & 2.7966 & 1 & 2.79661 & 568.5 & $<0.001$ \\
\hline Residual & 0.1722 & 35 & 0.00049 & & \\
\hline Total (Corr.) & 2.9688 & 36 & & & \\
\hline
\end{tabular}

Corel. Coef. $=0.97 ; R^{2}=94.2 \%$.

\section{Results}

Over the course of the experiments, larval growth and survival rates showed no abnormalities and similar patterns to those in a natural environment: for example, metamorphosis was reached in less than 22 days.

Although only four size groups were estimated, a relationship between total dry weight and larval size $(100-250 \mu \mathrm{m})$ was established: $D W=e^{(3.27+L \times 0.0154)}\left(R^{2}=99 \%\right)$.

The relationship based on a multiplicative model between larval size (range 112 to $330 \mu \mathrm{m}$ ) and respiratory rate showed a 0.9 correlation coefficient, explaining $88 \%$ of the variance (Table 1, Fig. 1).

$$
\operatorname{Ln}(\text { Resp. })=-16.669+3.273 \times \operatorname{Ln}(L) \quad(n=37) .
$$

A more conservative approach using oyster larval dry meat weight and respiratory rate was developed to establish a linear model explaining $94.5 \%$ of the variability (Table 2, Fig. 2):

$$
\text { Resp. }=-3.849 \times 10^{-4}+5.211 \times 10^{-6} \times T D W \quad(n=37) \text {. }
$$

The effect of exposure to CCA leachate on larval respiratory rate is shown in Figure 3. Tissue dry weight was used as a covariate (Table 3 ). Respiratory rate for larvae exposed to leachates from wood treated to $15 \mathrm{~kg} \mathrm{~m}^{-3} \mathrm{CCA}$ was significantly reduced in comparison to control larvae and to larvae exposed to leachate from wood treated to $5 \mathrm{~kg} \mathrm{~m}^{-3}$ (LSD Fisher test). Furthermore, leachates also increased the variability in respiratory rate (Fig. 3). 
Table 3. Chromated copper-arsenate (CCA) treatment effects on larval respiratory rate. ANCOVA results; co-variable is the larval dry meat weight $(n=52)$.

\begin{tabular}{|c|c|c|c|c|c|}
\hline Source & $\begin{array}{l}\text { Sum of Squares } \\
\left(\times 10^{-4}\right)\end{array}$ & $d f$ & $\begin{array}{c}\text { Mean Square } \\
\left(\times 10^{-4}\right)\end{array}$ & $F$ & Prob. \\
\hline \multicolumn{6}{|l|}{ Covariable } \\
\hline Dry meat weight & 2.968 & 1 & 2.968 & 160.1 & $<0.001$ \\
\hline \multicolumn{6}{|l|}{ Main effect } \\
\hline CCA treatment & 0.149 & 2 & 0.0747 & 4.03 & $<0.001$ \\
\hline Residual & 0.871 & 47 & 0.0185 & & \\
\hline Total & 3.962 & 50 & & & \\
\hline
\end{tabular}

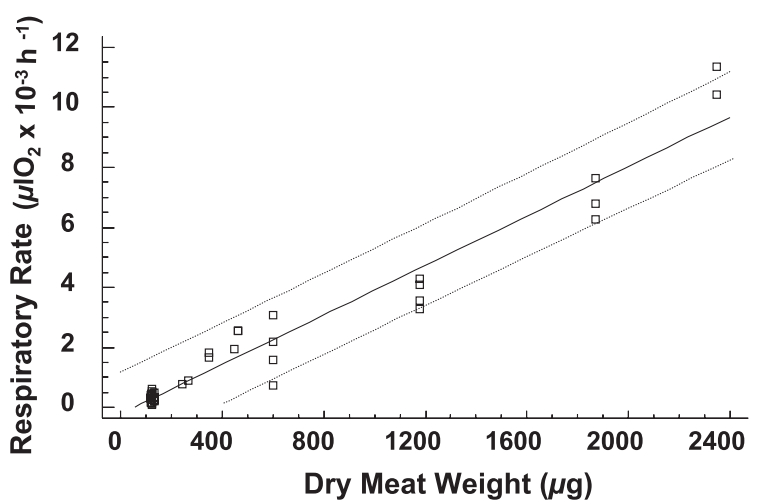

Fig. 2. Relationship between oyster larval dry meat weight and respiratory rate per larva, using a linear model $\left(R^{2}=94 \%, n=37\right)$ (95\% confidence limits).

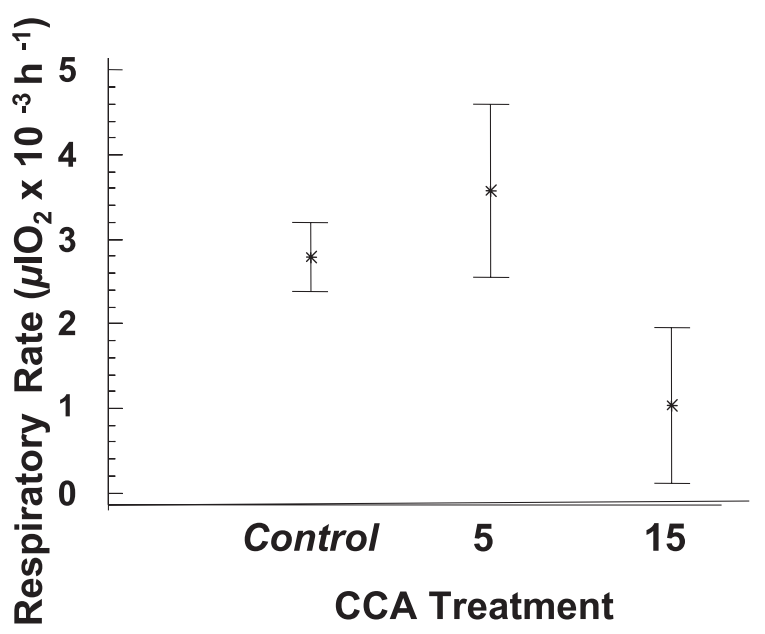

Fig. 3. ANCOVA results for the respiratory rates of $48 \mathrm{~h}$ oyster veligers: unexposed (control) and exposed to 5 and $15 \mathrm{~kg} \mathrm{~m}^{-3}$ leachate concentration. Covariable is larval dry meat weight (95\% confidence limits).

\section{Discussion}

The volumetric micro-respirometer method has been successfully used to estimate respiratory rates of juvenile oysters (Goulletquer et al. 1999). The present investigation demonstrates that this methodology can also be used to assess respiratory rates of early stages of larval development (48-hr veliger larvae), and the effects of contaminants on this rate. However, the need to use high concentrations of larvae to estimate physiological functions has been considered a critical issue, due to the density effect (Sprung 1984). Uncertainty still exists about the importance of the density effect and the evidence of whether larval densities affect individual respiration is conflicting. Hoegh-Guldberg and Manahan (1995) compared both coulometric and polarographic probe methods to assess $C$. gigas larval respiratory rates with 8 to 800 and with 80 larvae per respiration chamber respectively. When testing only a single larval size, no significant effect was detected with increasing density (over the range 4 to 400 individuals $/ \mathrm{ml}$ ), a similar finding to that of Marsh and Manahan (1999) for the Antarctic asteroids and echinoderms. In contrast, Macdonald (1988) found that the respiratory rate of scallop larvae fell by $35 \%$ as densities increased from 5 to 25 individuals per $\mathrm{cm}^{3}$. In our case, the volumetric method required only a relatively low larval density in most estimates, 50 larvae per chamber (100 larvae/ml), and therefore limited potential density bias. The volumetric method provided reproductible measurements and direct estimates comparable with those derived from biochemical loss equivalents (Gabbott and Holland 1973).

It is interesting to note that only a few relationships concerning $C$. gigas larval respiratory rates are available in the literature (Gerdes 1983; Hoegh-Guldberg and Manahan 1995). The larval size-weight relationship obtained in the present investigation was close to the Gerdes estimate and also confirmed previous respiratory estimates in spite of different experimental temperatures $\left(20^{\circ} \mathrm{C}\right.$ vs. $\left.25^{\circ} \mathrm{C}\right)$ (Fig. 4). Moreover, results are more homogeneous considering that Hoegh-Guldberg and Manahan (1995) and Gerdes (1983) calculated respiratory rates using ash free dry weight and dry weight respectively. Manahan et al. (1989) reported that physiological responses for large larvae approaching metamorphosis showed increasing variability, therefore decreasing the significance of length-based model. Although the use of allometric conversion to dry tissue weight facilitated increasing model significance, respiratory rate for large larvae was less variable than expected. However, the use of microrespirometer based on oxygen analysis using a colouximeter might further facilitate understanding of individual response as described by Peck and Prothero-Thomas (2002).

Ecotoxicological effects on respiration of pollutants were assessed using the CCA leachates. The initially higher variability in respiratory rate at the lower leachate concentration may be due to the higher swimming activity observed in C. gigas larvae in similar conditions reported by Praël et al. (2001). These authors also consider the possibility that the leachate has a direct physiologically stimulatory effect as well 


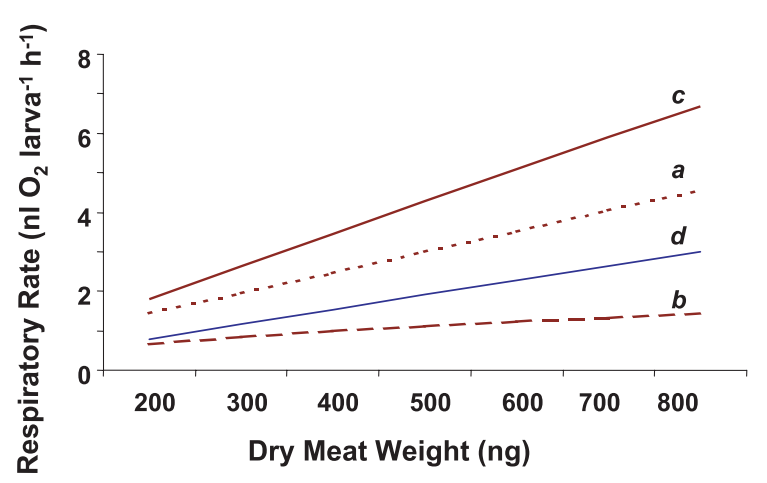

Fig. 4. Comparison of respiratory rate estimates for the present study (a), with the measurements of Hoegh-Guldberg and Manahan (1995) using (b) the coulometric method, (c) the polarographic oxygen sensor (calculated with ash free dry weight at $20^{\circ} \mathrm{C}$ ) and Gerdes (1983) (d) using a Clark electrode (calculated with dry weight at $\left.25^{\circ} \mathrm{C}\right)$.

as behavioural effect. The sharp decline in respiratory rate obtained for the leachate from wood treated to $15 \mathrm{~kg} \mathrm{~m}^{-3}$, may either indicate a direct physiological response causing reduction in respiration or a suppression of swimming activity. Although measurements of both "swimming activity" and "respiratory rate" indicators should be carried out in further studies, preliminary comparisons demonstrate that the "respiratory rate" indicator provides an earlier response to CCA pollutant effect than the swimming activity.

Acknowledgements. This work was carried out within the cooperation programme developed between Ifremer (France) and the Institute of Oceanography, University of Gdansk (Poland).

This work built upon the collaboration established under the Marine Science and Technology programme (MAST-III) of the European Union, under contract MAS2-CT94-0100 (PINTO Project). We are grateful to numerous colleagues at the IFREMER's research hatchery for producing and raising the oysters used for those experiments.

\section{References}

Bayne B.L., 1983, Physiological ecology of marine molluscan larvae. In: Wilbur K.M., Saleuddin S.M. (Eds.), The Mollusca, Academic Press, London, UK, pp. 299-343.

Bayne B.L., Newell R.C., 1983, Physiological energetics of marine molluscs. In: Wilbur K.M., Saleuddin S.M. (Eds.), The Mollusca, Academic Press, London, UK, pp. 407-515.

Bochenek E.A., Klinck J.M., Powell E.N., Hofmann E.E., 2001, A biochemically based model of the growth and development of Crassostrea gigas larvae. J. Shellfish Res. 20(1), 243-265.

Brown C.J., Eaton R.A., Cragg S.M., Goulletquer P., Nicolaidou A., Bebianno M.J., Icely J.D., Daniel G., Nilsson T., Pitman A.J. and Sawyer G.S., 2003, Assessment of effects of chromated copper arsenate (CCA)-treated timber on non-target benthos by investigation of fouling community development at seven European sites. Arch. Env. Contam. Toxicol. 45, 37-47.

Dekshenieks M.M., Hofmann E.E., Powell E.N., 1993, Environmental effects on the growth and development of
Eastern oyster, Crassostrea virginica (Gmelin, 1791) larvae: a modeling study. J. Shellfish Res. 12, 241-254.

Gabbott P.A., Holland D.L. 1973, Growth and metabolism of Ostrea edulis larvae. Nature, London 241, 475-476.

Gallager S.M., Mann R., 1986, Individual variability in lipid content of bivalve larvae quantified histochemically by absorption photometry. J. Plankton Res. 8, 927-937.

Gerdes D., 1983, The Pacific oyster Crassostrea gigas Part II. Oxygen consumption of larvae and adults. Aquaculture 31, 221-231.

Gnaiger E., Forstner H., 1983, Polarographic oxygen sensors. Aquatic and physiological applications. Berlin, Heidelberg, New York. Springer Verlag.

Goulletquer P., Héral M., Prou J., 1994, Combined effects of temperature-salinity on larval survival of the Eastern oyster Crassostrea virginica in the Maryland portion of the Chesapeake Bay (USA). Haliotis 23, 71-86.

Goulletquer P., Wolowicz M., Latala A., Geairon P., Huvet A., Boudry P., 1999, Comparative analysis of oxygen consumption rates between cupped oyster spat of Crassostrea gigas of French, Spanish and Taiwanese origins. Aquat. Living Resour. 12, 1-7.

Grunbaum B.W., Siegal B.V., Schultz A.R., Kirk P.L., 1955, Determination of oxygen uptake by tissue growth in an all glass differential microrespirometer. Microchim. Acta 6, 1069-1075.

Helm M.M., Millican P.E., 1977, Experiments in the hatchery rearing of Pacific oyster larvae (Crassostrea gigas Thunberg). Aquaculture 11, 1-12.

Héral M., 1989, L’ostréiculture française traditionnelle. In: Barnabé G. (Ed.), Aquaculture, Tec. \& Doc. 2, pp. 347-399.

Héral M., 1993, Why carrying capacity models are useful tools for management of bivalve mollusc culture. In: Dame R. (Ed.), Bivalve filter feeders in estuarine and coastal ecosystem processes. NATO ASI, Ser. G Ecolog. Sci. 33, pp. 455-477.

His E., Robert R., Dinet A., 1989, Combined effects of temperature and salinity on fed and starved larvae of the Mediterranean mussel Mytilus galloprovincialis and the Japanese oyster Crassostrea gigas. Mar. Biol. 110, 455-463.

Hoegh-Guldberg O., Manahan D.T., 1995, Coulometric measurement of oxygen consumption during development of marine invertebrate embryos and larvae. J. Exp. Biol. 198, 19-30.

Jaeckle W.B., Manahan D.T., 1989, Growth and energy imbalance during the development of lecithotrophic molluscan larvae Haliotis rufescens. Biol. Bull. 177, 237-246.

Lu Y.T., Blake N.J., Torres J.J., 1999, Oxygen consumption and ammonia excretion of larvae and juveniles of the bay scallop, Argopecten irradians concentricus (Say). J. Shellfish Res. 18, 419-423.

Macdonald B.A., 1988, Physiological energetics of Japanese scallop Patinopecten yessoensis larvae. J. Exp. Mar. Biol. Ecol. 120, 155-170.

Manahan D.T., Jaeckle W.B., Nourizadeh S.D., 1989, Ontogenic changes in the rates of amino acid transport from seawater by marine invertebrate larvae (Echinodermata, Echiura, Mollusca). Biol. Bull. 176, 161-168.

Marsh A.G., Manahan D.T., 1999, A method for accurate measurements of the respiration rates of marine invertebrate embryos and larvae. Mar. Ecol. Prog. Ser. 184, 1-10.

Millar R.H., Scott J.M., 1967, The larvae of the oyster Ostrea edulis during starvation. J. Mar. Biol. Assoc. UK 47, 475-484.

Olson R.R., Bosch I., Pearse J.S., 1987, The hypothesis of larval starvation examined in for the asteroid Odontaster validus. Limnol. Oceanogr. 32, 686-690.

Peck L.S., Whitehouse M.J., 1999, An improved desorber design for use in colouximetry. J. Exp. Mar. Biol. Ecol. 163, 163-167. 
Peck L.S., Prothero-Thomas E., 2002, Temperature effects on the metabolism of larvae of the Antarctic starfish Odontaster validus, using a novel micro-respirometry method. Mar. Biol. 141, 271-276.

Powell E.N., Bochenek E.A., Klinck J.M., Hofmann E.E., 2002, Influence of food quality and quantity on the growth and development of Crassostrea gigas larvae: a modelling approach. Aquaculture 210, 89-117.

Praël A., Cragg S., Henderson S.M., 2001, Behavioral responses of veliger larvae of Crassostrea gigas to leachate from wood treated with copper-chrome-arsenic (CCA): a potential bioassay of sublethal environmental effects of contaminants. J. Shellfish Res. 20, 267-273.

Ren J.S., Ross A.H., 2001, A dynamic energy budget model of the Pacific oyster Crassostrea gigas. Ecol. Model. 142, 105-120.

Roland W.G., Broadley T.A., 1989, Investigations into remote setting Pacific oyster larvae. J. Shellfish Res. 8, 415-416.
Smaal A.C., Widdows J., 1994, The scope for growth of bivalves as an integrated response parameter in biological monitoring. In: Kramer K.J.M. (Ed.), Biomonitoring of coastal waters and estuaries, CRC Press, Chap. 11, pp. 247-268.

Sprung M., 1984, Physiological energetics of mussel larvae (Mytilus edulis). III. Respiration. Mar. Ecol. Prog. Ser. 18, 171-178.

Walne P.R., 1965, Observations on the influence of food supply and temperature on the feeding and growth of the larvae of Ostrea edulis L. Fish. Invest., London, Ser. 2, 24, 1-45.

Zeuthen E., 1947, Body size and metabolic rate in the animal kingdom with special regard to the marine microfauna. C. R. Trav. Lab. Carlsberg, Ser. Chim. 26, 17-161.

Zurzycki J., Starzecki W., 1971, Volumetric methods. In: Šesták Z., Latský J., Jarvis P.G. (Eds.), Plant Photosynthetic Production: Manual of Methods, Dr W. Junk N. V. Publ., The Hague, pp. 257-270. 